\title{
Analisis Faktor-Faktor yang Mempengaruhi Keterlambatan Laporan Audit
}

\author{
Robby Krisyadi ${ }^{1}$, Noviyanti ${ }^{2 *}$ \\ Universitas Internasional Batam ${ }^{1,2}$ \\ ${ }^{1)}$ robby.krisyadi@uib.ac.id, ${ }^{2)}$ novii.ling@gmail.com
}

\author{
*Penulis Korespondensi \\ Diajukan : 13 Nopember 2021 \\ Disetujui $\quad: 99 / x x x / 9999$ \\ Dipublikasi : : 1 Januari 2022
}

\begin{abstract}
Audit delay will directly affect the timeliness of the publication of the company's financial statements and affect investors' views of the company. The delay in the audit report is the difference between the end date of fiscal year and the date of issuance of the audit report. This study aims to determine the factors that affect delay of audit report. The population of research are companies listed in Indonesia Stock Exchange in 2016 - 2020. The sampling technique used purposive sampling method with 1870 annual report processed. The data analysis technique of this research uses multiple regression and assisted by SPSS software and Eviews software. The result of this research showed that audit opinion and profitability is significantly negative to audit delay, and firm size is significantly positive to audit delay, whereas audit effort, public accounting firm size, debt and ownership concentration have no effect to audit delay. The results of this study are expected to contribute to strengthening agency theory in safeguarding the interests of agents and principals by submitting financial statements in a transparent and timely manner to prevent information asymmetry, as well as strengthening signal theory in explaining the factors for the spread of good news and bad news of companies to investors. In addition, practical contributions for company management can be used as a source of information to find solutions to improve the timeliness of submitting financial reports, for auditors it is expected to be a guide in preparing audit procedures that are more effective in overcoming factors that cause delays in audit reports, and for service authorities. The financial statements are expected to be the basis for policies to strengthen supervision of companies listed on the IDX in submitting annual reports in a timely manner.
\end{abstract}

Keywords: Audit Delay, Annual Report, Agency Theory, Signalling Theory

\section{PENDAHULUAN}

Laporan tahunan merupakan sumber informasi mengenai kinerja perusahaan yang dimanfaatkan oleh pemangku kepentingan dalam pengambilan keputusan. Laporan tahunan yang melibatkan auditor eksternal akan meningkatkan kepercayaan pemangku kepentingan terhadap laporan tahunan yang telah disajikan (Diana dan Maggy, 2018). Auditor menggunakan waktu yang lebih lama untuk proses audit akan mengakibatkan keterlambatan laporan audit sehingga laporan tahunan tidak dapat disajikan dengan tepat waktu. Keterlambatan laporan audit merupakan selisih hari antara tanggal penerbitan laporan audit dengan tanggal akhir tahun fiskal (Ningsih dan Widhiyani, 2015).

Keterlambatan laporan audit dapat dijelaskan dengan teori agensi dan teori sinyal. Agent merupakan pihak pengelola perusahaan sehingga dapat mengetahui kondisi keuangan perusahaan setiap saat, sedangkan principal hanya dapat mengetahui kondisi perusahaan melalui laporan keuangan (Jensen dan Meckling, 1976). Individu yang memprioritaskan kepentingan pribadi akan memicu asimetris informasi yang 
mengakibatkan terjadinya konflik keagenan. Principal membutuhkan jasa auditor untuk memastikan kualitas informasi yang telah disajikan oleh manajemen perusahaan (Butarbutar \& Hadiprajitno, 2017). Penyampaian laporan keuangan setelah audit dengan tepat waktu merupakan salah satu pencegahan asimetris informasi karena principal dapat menerima informasi perusahaan secara transparan dan tepat waktu.

Keterlambatan laporan audit merupakan bad news bagi investor. Investor akan menerima sinyal negatif yang menunjukkan perusahaan sedang dalam kondisi kurang sehat sehingga mempengaruhi keputusan dan pandangan investor terhadap perusahaan (Zebriyanti \& Subardjo, 2016). Sinyal negatif yang disebarkan oleh perusahaan akan mempengaruhi pergerakan harga saham perusahaan (Sari dan Priyadi, 2016).

Penelitian ini akan menguji pengaruh upaya audit, opini audit, ukuran kantor akuntan publik, ukuran perusahaan, leverage, profitabilitas, konsentrasi kepemilikan, dan pergantian auditor terhadap keterlambatan laporan audit pada perusahaan yang terdaftar di BEI tahun 2016-2020. Berdasarkan Surat Keputusan Bapepam-LK Nomor: Kep431/BL/2012 perusahaan go public diwajibkan menyampaikan laporan tahunan yang berisi laporan keuangan tahunan setelah audit paling lambat 120 hari setelah tahun buku berakhir. Namun setiap periode terdapat perusahaan yang terlambat menyampaikan laporan tahunannya. Pada periode 2016 terdapat 17 perusahaan (Melani, 2017), periode 2017 terdapat 70 perusahaan (idx.co.id), periode 2018 terdapat 24 perusahaan (Sidik, 2019), dan periode 2019 terdapat 80 perusahaan (Gumilar, 2020) yang terlambat menyampaikan laporan keuangan. Berdasarkan Kep-00089/BEI/10-2020 batas penyampaian laporan tahunan telah diperpanjang menjadi 180 hari oleh BEI usai pandemi Covid-19, namun masih terdapat 52 perusahaan yang terlambat menyampaikan laporan tahunan 2020 (Melani, 2021). Keterlambatan laporan audit menjadi masalah penting untuk diteliti karena berpengaruh secara langsung terhadap penerbitan laporan tahunan perusahaan (Triyaningtyas dan Sudarno, 2019). Terdapat kenaikan dan penurunan kasus keterlambatan penyampaian laporan dari tahun 2016-2020 sehingga peneliti tertarik untuk meneliti faktor penyebab keterlambatan laporan audit.

Penelitian ini diharapkan dapat memberikan kontribusi untuk memperkuat teori agensi dalam menjaga kepentingan agent dan principal dengan menyampaikan laporan keuangan secara transparan dan tepat waktu serta memperkuat teori sinyal dalam menjelaskan faktor penyebaran good news dan bad news perusahaan kepada investor. Selain itu, kontribusi praktisnya diharapkan dapat menjadi sumber informasi bagi manajemen untuk mencari solusi dalam meningkatkan ketepatan waktu penyampaian laporan keuangan dengan menghindari terjadinya keterlambatan laporan audit, bagi auditor diharapkan dapat menjadi pedoman dalam menyusun prosedur audit yang lebih efektif dengan kondisi klien yang berbeda untuk meminimalisir terjadinya keterlambatan laporan audit, dan bagi pihak otoritas jasa keuangan diharapkan dapat menjadi dasar kebijakan untuk memperkuat pengawasan pada perusahaan yang terdaftar di BEI menyampaikan laporan keuangannya dengan tepat waktu.

\section{Teori Agensi}

\section{STUDI LITERATUR}

Teori agensi merupakan hubungan kontrak antar dua pihak (principal dan agent). Principal merupakan pihak pemegang saham dan agent merupakan manajer perusahaan. Konflik agensi akan terjadi saat pihak principal dan agent ingin memperoleh kepentingan masing-masing sehingga terjadinya perbedaan pendapat (Jensen dan Meckling, 1976). Konflik agensi akan muncul ketika adanya asimetris informasi antara agent dan principal. Manajer sebagai agent yang telah mengontrol kegiatan operasional akan mengetahui informasi mengenai perusahaan yang lebih baik, sedangkan pemegang saham sebagai principal memiliki keterbatasan akses terhadap informasi perusahaan. Pemegang saham 
dapat mengetahui informasi perusahaan berdasarkan laporan keuangan yang disajikan. Laporan keuangan yang diaudit akan meningkatkan kualitas laporan dan menginformasikan kondisi perusahaan secara transparan (Hassan, 2016). Penyampaian laporan audit dengan tepat waktu dapat mencegah terjadinya asimetris informasi karena principal dapat menerima informasi dengan tepat waktu (Zebriyanti \& Subardjo, 2016).

\section{Teori Sinyal}

Teori sinyal merupakan sinyal yang diberikan oleh perusahaan kepada investor berdasarkan kondisi sebenarnya dalam perusahaan (Restianti \& Agustina, 2018). Sinyal dapat diberikan dalam bentuk laporan keuangan. Sinyal yang diterima oleh investor akan berupa sinyal positif ataupun negatif. Sinyal yang diberikan perusahaan akan menjadi bahan pertimbangan investor untuk pengambilan keputusan. Perusahaan yang mengalami keterlambatan laporan audit semakin panjang akan mengakibatkan laporan keuangan perusahaan terlambat diterbitkan sehingga mempengaruhi pergerakan harga sahamnya (Zebriyanti \& Subardjo, 2016). Ketepatan waktu menyampaikan laporan kepada publik merupakan sinyal positif berupa good news yang diterima oleh investor. Investor akan menerima sinyal negatif (bad news) jika perusahaan tidak menerbitkan laporan tahunan dengan tepat waktu (Sari dan Priyadi, 2016).

\section{Keterlambatan Laporan Audit}

Keterlambatan laporan audit merupakan selisih hari sejak penutupan tahun fiskal hingga penerbitan laporan audit (Oradi, 2021). Keterlambatan laporan audit akan mengakibatkan laporan keuangan ikut mengalami keterlambatan penyampaian. Hal ini akan mengakibatkan kekurangan informasi laporan yang tersajikan karena untuk pengambilan keputusan membutuhkan informasi yang tepat waktu (Fujianti \& Satria, 2020). Keterlambatan laporan audit terjadi karena auditor menggunakan waktu yang banyak untuk audit laporan keuangan perusahaan. Semua perusahaan berusaha meminimalkan keterlambatan laporan audit karena berpengaruh secara langsung terhadap ketepatan waktu penerbitan laporan keuangan untuk meningkatkan efisiensi pasar.

\section{Upaya Audit dan Keterlambatan Laporan Audit}

Upaya audit adalah konteks praktik audit yang bergantung pada sifat aset yang akan diverifikasi (Khoufi dan Khoufi, 2018). Variabel tersebut digunakan oleh Ahmad dan Abidin (2008) sebagai variabel independen. Mengacu kepada hasil penelitiannya, upaya audit berpengaruh positif terhadap keterlambatan laporan audit. Jika perusahaan memiliki upaya audit tinggi maka upaya auditor dalam proses memverifikasi akun persediaan dan piutang usaha akan semakin tinggi sehingga akan mengakibatkan keterlambatan laporan audit yang semakin panjang (Ahmad dan Abidin, 2008). Proporsi persediaan dan piutang suatu perusahaan semakin besar, auditor harus berupaya lebih besar untuk memverifikasi akun-akun terkait untuk memastikan saldo yang tertera di neraca telah sesuai dengan kondisi perusahaan yang sebenarnya (Lathifatun, 2020). Dalam proses verifikasi akun, auditor harus lebih focus untuk memastikan kualitas dan kebenaran atas saldo yang disajikan (Dewi, 2021).

\section{$\mathrm{H}_{1}$ : Adanya pengaruh positif antara upaya audit dengan keterlambatan laporan audit}

\section{Opini Audit}

Opini audit merupakan pernyataan dari auditor mengenai laporan yang disajikan oleh perusahaan. Opini wajar tanpa pengecualian merupakan opini yang diberikan auditor sebagai pernyataan perusahaan sedang dalam kondisi sehat dan tidak ada salah saji dalam laporan keuangannya sehingga keterlambatan laporan audit akan semakin pendek 
(Triyaningtyas dan Sudarno, 2019). Berdasarkan penelitian Baldacchino et al. (2017) dan Habib (2014), opini audit berpengaruh signifikan positif terhadap keterlambatan laporan audit sehingga opini selain opini wajar tanpa pengecualian akan mengakibatkan keterlambatan laporan audit semakin panjang. Hal tersebut dikarekan perusahaan yang telah mendapatkan opini selain wajar tanpa pengecualian akan berusaha menahan berita buruk supaya investor tidak menilai buruk terhadap perusahaan. Manajemen akan melakukan negosiasi serta konsultasi kepada pihak auditor sehingga terjadinya keterlambatan laporan audit (Arifuddin et al., 2017 dan Roswyda et al., 2019).

$\mathrm{H}_{2}$ : Adanya pengaruh negatif antara opini audit dengan keterlambatan laporan audit.

\section{Ukuran Kantor Akuntan Publik dan Keterlambatan Laporan Audit}

Ukuran kantor akuntan publik adalah ukuran badan usaha berizin yang melakukan audit terhadap laporan keuangan perusahaan dengan menaungi akuntan publik profesional dalam proses audit (Triyaningtyas \& Sudarno, 2019). Menurut Sari dan Priyadi (2016) dan Verawati dan Wirakusuma (2016) ukuran kantor akuntan publik akan berpengaruh negatif terhadap keterlambatan laporan audit, karena KAP internasional memiliki sumber daya dan kinerja yang sangat bagus sehingga waktu yang digunakan saat melakukan pengauditan pada suatu laporan keuangan akan semakin singkat. KAP yang berskala besar atau internasional (Big4) dapat mempersingkat keterlambatan laporan audit dengan kapasitas personel yang lebih besar dibanding KAP biasa (Vuko dan Cular, 2014).

$\mathrm{H}_{3}$ : Adanya pengaruh negatif antara ukuran KAP dengan keterlambatan laporan audit.

\section{Ukuran Perusahaan dan Keterlambatan Laporan Audit}

Ukuran perusahaan adalah skala suatu perusahaan yang dinilai berdasarkan total aset yang dimiliki. Perusahaan skala besar memiliki pengendalian internal kuat yang dapat diandalkan oleh auditor sehingga mengurangi jumlah pekerjaan audit yang diperlukan pada akhir tahun (Habib, 2014). Perusahaan besar umumnya memiliki tekanan yang lebih besar untuk publikasi laporan keuangan sehingga perusahaan akan memberikan tekanan kepada pihak auditor untuk menyelesaikan proses audit dalam waktu yang singkat (Sharad, 2014; Vuko dan Cular, 2014; Suryanto, 2016). Tekanan yang diberikan pemangku kepentingan atas ketepatan waktu penyampaian laporan audit akan mendorong perusahaan dan auditor untuk menyelesaikan laporan audit dengan tepat waktu (Dura, 2017). Hasil penelitian sejalan dengan Askari dan Moradpour (2016) dan Lestari dan Nuryatno (2018), perusahaan yang memiliki skala lebih besar akan mengalami keterlambatan laporan audit yang lebih pendek. Kondisi tersebut dikarenakan perusahaan berskala besar memiliki sistem informasi yang telah sesuai dengan peraturan berlaku sehingga akan mengurangi terjadinya keterlambatan laporan audit.

$\mathrm{H}_{4}$ : Adanya pengaruh negatif antara ukuran perusahaan dengan keterlambatan laporan audit.

\section{Leverage dan Keterlambatan Laporan Audit}

Leverage adalah rasio yang digunakan untuk mengukur banyaknya aset perusahaan yang dibiayai oleh hutang (Julia, 2020 dan Wiryakriyana dan Widhiyani, 2017). Leverage digunakan sebagai variabel independen oleh Alkhatib dan Marji (2012) dan Vuko dan Cular (2014) dengan hasil penelitian leverage berpengaruh positif terhadap keterlambatan laporan audit. Apabila leverage suatu perusahaan tinggi maka keterlambatan laporan audit akan semakin tinggi. Hubungan tersebut dikarenakan terdapat risiko gagal bayar dari perusahaan atas hutang yang dimilikinya sehingga tingkat keakuratan laporan keuangan akan diragukan. Auditor harus menggunakan waktu yang lebih lama untuk menyelesaikan proses audit (Roswyda et al., 2019). 


\section{$\mathrm{H}_{5}$ : Adanya pengaruh positif antara leverage dengan keterlambatan laporan audit.}

\section{Profitabilitas dan Keterlambatan Laporan Audit}

Profitabilitas adalah indikator kemampuan perusahaan untuk menghasilkan laba dengan mengelola aset yang dimilikinya (Rahmawati dan Suryono, 2015). Perusahaan akan meminta seorang auditor untuk melakukan penjadwalan ulang proses audit apabila laporan keuangan perusahaan menunjukkan nominal negatif pada laporan laba rugi perusahaan karena akan mempengaruhi pandangan investor terhadap perusahaan (Herdjiono dan Sutanti, 2018). Profitabilitas suatu perusahaan semakin tinggi, maka keterlambatan laporan audit akan semakin singkat. Hasil tersebut juga dikemukakan oleh Rahmawati dan Suryono (2015); Mazkiyani dan Handoyo (2017); Fujianti dan Satria (2020), perusahaan dengan nilai profitabilitas tinggi akan menunjukkan perusahaan kuat untuk mempertahankan kelangsungan hidup perusahaan. Perusahaan akan berusaha menyampaikan informasi positif kepada investor dengan tepat waktu (Mazkiyani dan Handoyo, 2017). Laba yang dihasilkan perusahaan merupakan sinyal positif yang dapat mempengaruhi keputusan investor, sehingga perusahaan akan menerbitkan laporan dalam waktu yang singkat (Abdillah et al., 2019).

\section{$\mathrm{H}_{6}$ : Adanya pengaruh negatif antara profitabilitas dengan keterlambatan laporan audit.}

\section{Konsentrasi Kepemilikan dan Keterlambatan Laporan Audit}

Konsentrasi kepemilikan adalah persentase kepemilikan pemegang saham terbesar selain publik pada suatu perusahaan. Berdasarkan penelitian Butarbutar dan Hadiprajitno (2017), konsentrasi kepemilikan berpengaruh signifikan negatif terhadap keterlambatan laporan audit. Kepemilikan terkonsentrasi yang semakin tinggi, pemegang saham akan memiliki fungsi monitoring dan kontrol yang lebih kuat sehingga keterlambatan laporan audit akan lebih singkat (Shin et al., 2016). Hasil tersebut bertolak belakang dengan hasil penelitian Hassan (2016), konsentrasi kepemilikan berpengaruh positif terhadap keterlambatan laporan audit. Hasil tersebut menunjukkan bahwa, semakin tinggi kepemilikan terkonsentrasi, pemegang saham akan memprioritaskan kepentingan pribadi sehingga kualitas pengungkapan menjadi rendah dan keterlambatan laporan audit semakin panjang.

\section{$\mathrm{H}_{7}$ : Adanya pengaruh negatif antara konsentrasi kepemilikan dengan keterlambatan laporan audit.}

\section{Pergantian Auditor dan Keterlambatan Laporan Audit}

Pergantian auditor pada suatu perusahaan akan mempengaruhi keterlambatan laporan audit, karena tim auditor baru harus menggunakan waktu yang lebih banyak untuk mengenal perusahaan yang sedang diaudit (Putra dan Wilopo, 2017). Independensi bagi tim auditor akan lebih terjaga apabila perusahaan melakukan pergantian auditor (Verawati dan Wirakusuma, 2016). Pergantian auditor akan memperpanjang penggunaan waktu oleh auditor untuk menyelesaikan audit, hal tersebut dikarenakan auditor baru harus mengenal ulang perusahaan yang bersangkutan dengan berkomunikasi dengan auditor sebelumnya atau melakukan wawancara kepada pihak perusahaan (Wiryakriyana dan Widhiyani, 2017).

\section{METODE}

Penelitian menggunakan pendekatan kuantitatif dengan sumber data penelitian sekunder berupa laporan tahunan perusahaan. Penelitian ini akan menguji hubungan antara upaya audit, opini audit, ukuran kantor akuntan publik, ukuran perusahaan, leverage, profitabilitas, dan konsentrasi kepemilikan terhadap keterlambatan laporan audit dengan 
adanya pergantian auditor sebagai variabel kontrol. Populasi penelitian ini adalah perusahaan yang terdaftar pada BEI tahun 2016-2020. Sampel yang digunakan telah diseleksi menggunakan teknik purposive sampling, sejumlah 388 perusahaan yang akan dijadikan sampel penelitian. Terdapat 70 data outlier yang akan dihapus sehingga total sampel yang akan diuji sejumlah 1870 sampel. Data penelitian telah dikumpulkan melalui content analysis method. Metode tersebut akan melakukan analisa konten pada laporan keuangan perusahaan yang terdaftar di BEI tahun 2016-2020. Penelitian ini telah menggunakan metode regresi data panel. Penelitian ini akan mendeteksi data outlier dengan bantuan software SPSS. Kemudian melakukan uji Chow dan uji Hausman untuk pemilihan model terbaik di antara common effect model, fixed effect model dan random effect model, serta pengujian koefisien determinasi, uji F dan uji t dengan software Eviews. Penelitian ini menggunakan regresi data panel dengan rumus persamaan sebagai berikut:

$$
\mathrm{Y}=\mathrm{a}+\beta \mathrm{X}_{1}+\beta \mathrm{X}_{2}+\beta \mathrm{X}_{3}+\beta \mathrm{X}_{4}+\beta \mathrm{X}_{5}+\beta \mathrm{X}_{6}+\beta \mathrm{X}_{7}+\beta \mathrm{X}_{8}+e
$$

Keterangan :

$\mathrm{Y}=$ Keterlambatan laporan audit

$\mathrm{a}=$ Konstan

$\mathrm{X}_{1}=$ Upaya Audit

$\mathrm{X}_{2}=$ Opini Audit

$\mathrm{X}_{3}=$ Ukuran Kantor Akuntan Publik

$\mathrm{X}_{4}=$ Ukuran Perusahaan

$\mathrm{X}_{5}=$ Hutang

$\mathrm{X}_{6}=$ Profitabilitas

$\mathrm{X}_{7}=$ Konsentrasi Kepemilikan

$\mathrm{X}_{8}=$ Pergantian Auditor

$e=$ eror

\section{Definisi Operasional dan Pengukuran Variabel Keterlambatan Laporan Audit}

Keterlambatan laporan audit merupakan suatu proses penyelesaian audit yang mengalami penundaan akibat beberapa faktor (Roswyda et al., 2019). Pengukuran variabel ini adalah selisih hari antara tanggal penerbitan laporan audit dengan tanggal akhir tahun fiskal perusahaan.

\section{Upaya Audit $\left(\mathbf{X}_{1}\right)$}

Upaya audit adalah proses audit yang bergantung pada sifat aset perusahaan yang akan diverifikasi (Khoufi dan Khoufi, 2018). Skala pengukuran variabel ini menggunakan rasio dengan rumus sebagai berikut:

\section{Opini Audit ( $\left.\mathbf{X}_{2}\right)$}

$$
\text { Upaya Audit }=\frac{\text { Total Persediaan }+ \text { Piutang Usaha }}{\text { Total Aset }}
$$

Opini audit adalah ungkapan auditor untuk menyatakan opini terhadap suatu laporan keuangan yang sedang diaudit dengan tujuan untuk menyatakan kewajaran dari sebuah laporan keuangan berdasarkan PSAK atau aturan yang berlaku (Baldacchino et al., 2017). Variabel opini audit akan diukur dengan variabel dummy yang diklasifikasikan dan diberikan kode 1 untuk opini wajar tanpa pengecualian, dan opini lainnya yang akan diberikan kode 0 . 
Owner: Riset \& Jurnal Akuntansi

e -ISSN : 2548-9224 | p-ISSN : 2548-7507

Volume 6 Nomor 1, Januari 2022

DOI : https://doi.org/10.33395/owner.v6i1.541

\section{Ukuran Kantor Akuntan Publik $\left(\mathbf{X}_{3}\right)$}

Ukuran KAP adalah ukuran badan usaha yang memiliki izin untuk audit laporan keuangan suatu perusahaan (Triyaningtyas dan Sudarno, 2019). Ukuran KAP diukur dengan variabel dummy, variabel tersebut akan diklasifikasikan dan diberi kode 1 untuk KAP big four dan 0 untuk KAP non big four.

\section{Ukuran Perusahaan $\left(\mathbf{X}_{4}\right)$}

Ukuran perusahaan adalah skala perusahaan yang dikategorikan berdasarkan besar atau kecilnya perusahaan (Fiatmoko dan Anisykurlillah, 2015). Variabel ini akan diukur dengan logaritma total aset perusahaan.

\section{Leverage $\left(\mathrm{X}_{5}\right)$}

Leverage adalah indikator banyaknya aset perusahaan yang dibiayai oleh hutang (Julia, 2020). Skala pengukuran variabel ini menggunakan rasio dengan rumus sebagai berikut:

\section{Profitabilitas $\left(\mathbf{X}_{\mathbf{6}}\right)$}

$$
D A R=\frac{\text { Total Hutang }}{\text { Total Aset }}
$$

Profitabilitas adalah indikator untuk mengukur kemampuan perusahaan dalam mencetak laba (Sari dan Priyadi, 2016). Skala pengukuran variabel ini menggunakan rasio dengan rumus sebagai berikut:

\section{Konsentrasi Kepemilikan $\left(\mathbf{X}_{7}\right)$}

$$
R O A=\frac{\text { Laba Bersih }}{\text { Total Asset }}
$$

Konsentrasi kepemilikan adalah kepemilikan terbesar selain publik pada suatu perusahaan. Konsentrasi kepemilikan diukur dengan persentase kepemilikan saham terbesar pada suatu perusahaan, kecuali publik.

\section{Pergantian Auditor $\left(\mathbf{X}_{8}\right)$}

Pergantian auditor adalah berhentinya kerjasama antar perusahaan dan auditor lama kemudian mengangkat auditor baru berdasarkan kebijakan internal (Wiryakriyana dan Widhiyani, 2017). Variabel tersebut akan diukur menggunakan variabel dummy dengan diberikan kode 1 apabila klien melakukan aktivitas pergantian auditor dan 0 apabila tidak melakukan aktivitas pergantian auditor.

\section{Uji Chow}

\section{HASIL}

Tabel 1. Hasil Uji Chow

\begin{tabular}{|l|c|c|}
\hline Effect Test & Prob & Kesimpulan \\
\hline Cross-section Chi-square & 0,0000 & Fixed Effect Model \\
\hline
\end{tabular}

Sumber : Data sekunder yang telah diolah, 2021

Hasil pengujian di atas menunjukkan nilai probabilitas sebesar 0,0000. Dengan hasil uji probabilitas yang menunjukkan nilai dibawah 0,05 maka dapat disimpulkan diantara Common Effect Model dan Fixed Effect Model, Fixed Effect Model akan dipilih untuk pengujian ini dan dilanjutkan ke tahap uji Hausman.

\section{Uji Hausman}

Tabel 2. Hasil Uji Hausman

\begin{tabular}{|l|c|c|}
\hline Test Summary & Prob & Kesimpulan \\
\hline Cross-section random & 0,0013 & Fixed Effect Model \\
\hline
\end{tabular}


Owner: Riset \& Jurnal Akuntansi

e -ISSN : 2548-9224 | p-ISSN : 2548-7507

Volume 6 Nomor 1, Januari 2022

DOI : https://doi.org/10.33395/owner.v6i1.541

Sumber : Data sekunder yang telah diolah, 2021

Pada hasil pengujian yang ditampilkan pada Tabel 2, nilai probabilitas adalah 0,0011. Dengan hasil uji probabilitas yang menunjukkan hasil dibawah 0,05 maka dapat disimpulkan diantara Random Effect Model dan Fixed Effect Model, penggunaan Fixed Effect Model merupakan model terbaik pada penelitian ini.

\section{Koefisien Determinasi}

Tabel 3. Hasil Uji Koefisien Determinasi

\begin{tabular}{|l|c|}
\hline Variabel Dependen & Adjusted $R$-Square \\
\hline Keterlambatan Laporan Audit & 0,349637 \\
\hline
\end{tabular}

Sumber : Data sekunder yang telah diolah, 2021

Pengujian koefisien determinasi $\left(R^{2}\right)$ dilakukan untuk menjelaskan seberapa banyak persentase keterkaitan antara variabel independen dan variabel dependen. Berdasarkan nilai $R^{2}$ yang telah dihasilkan, terdapat $34,96 \%$ dari variabel keterlambatan laporan audit dapat dijelaskan oleh upaya audit, opini audit, ukuran kantor akuntan publik, ukuran perusahaan, leverage, profitabilitas, dan konsentrasi kepemilikan. Adapun 65,04\% lainnya dipengaruhi oleh variabel lain yang tidak diungkapkan dalam model penelitian.

\section{Uji F}

Tabel 4. Hasil Uji F

\begin{tabular}{|l|c|c|}
\hline Variabel Dependen & Sig. & Kesimpulan \\
\hline Keterlambatan Laporan Audit & 0,000000 & Signifikan \\
\hline
\end{tabular}

Sumber : Data sekunder yang telah diolah, 2021

Proses uji F dilakukan untuk mengetahui apakah variabel independen pada penelitian ini berpengaruh secara bersamaan (simultan) terhadap variabel dependen. Berdasarkan Tabel 4, hasil uji $\mathrm{F}$ menunjukkan nilai probabilitas lebih kecil dari 0,05 yaitu 0,000000. Nilai tersebut mencerminkan variabel independen berpengaruh secara simultan terhadap variabel keterlambatan laporan audit.

\section{Uji t}

Tabel 5. Hasil Uji t

\begin{tabular}{|l|r|r|c|}
\hline Variabel & \multicolumn{1}{|c|}{ Coefficients } & \multicolumn{1}{c|}{ Prob. } & Kesimpulan \\
\hline C & $-105,4611$ & 0,1102 & \\
\hline UPAUD & $-13,25454$ & 0,1391 & Tidak Signifikan \\
\hline OPAUD & $-41,75680$ & 0,0000 & Signifikan Negatif \\
\hline UKKAP & $-0,911892$ & 0,8048 & Tidak Signifikan \\
\hline UKP & 8,361382 & 0,0003 & Signifikan Positif \\
\hline HTG & $-0,703385$ & 0,4814 & Tidak Signifikan \\
\hline PROFT & $-26,41374$ & 0,0000 & Signifikan Negatif \\
\hline KNST & $-2,272424$ & 0,7881 & Tidak Signifikan \\
\hline PA & $-1,714341$ & 0,3495 & Tidak Signifikan \\
\hline
\end{tabular}

Sumber : Data sekunder yang telah diolah, 2021

Uji t dapat mencerminkan pengaruh variabel bebas terhadap variabel terikat dalam penelitian yang sedang dijalankan. Jika nilai probabilitas menunjukkan hasil lebih kecil dari 0,05 , maka variabel bebas memiliki pengaruh yang signifikan terhadap variabel terikat. 
Apabila nilai probabilitas lebih besar dari 0,05 maka tidak terdapat pengaruh yang signifikan dari variabel independen kepada variabel dependen.

Arah positif dan arah negatif dari pengaruh suatu variabel independen kepada variabel dependen akan dicerminkan pada nilai coefficient yang dihasilkan. Apabila nilai coefficient negatif, maka variabel independen berpengaruh secara negatif terhadap variabel dependen, sedangkan jika nilai coefficient positif maka variabel independen berpengaruh secara positif terhadap variabel dependen.

\section{Upaya Audit dan Keterlambatan Laporan Audit}

Hasil uji hipotesis menunjukkan nilai probabilitas yang lebih besar dari 0,05 yaitu 0,1391 sehingga dapat dinyatakan bahwa upaya audit tidak berpengaruh terhadap keterlambatan laporan audit. Maka H1 ditolak. Perusahaan yang memiliki upaya audit yang tinggi tidak akan mempengaruhi keterlambatan laporan audit karena auditor telah memiliki pedoman standar audit yang dipahami. Auditor memiliki pengalaman dalam menghadapi masalah pengauditan seperti besarnya persediaan dan piutang usaha perusahaan yang menghasilkan upaya audit yang tinggi sehingga auditor akan bertindak profesional dalam proses audit dan menghindari terjadinya keterlambatan laporan audit.

\section{Opini Audit dan Keterlambatan Laporan Audit}

Hasil uji hipotesis menunjukkan nilai probabilitas yang lebih kecil adri 0,05 yaitu 0,0000 dan nilai koefisien sebesar $-41,75680$ maka dapat disimpulkan bahwa opini audit berpengaruh signifikan negatif terhadap keterlambatan laporan audit. Maka H2 diterima. Opini dari auditor merupakan cerminan dari kondisi keuangan perusahaan. Perusahaan yang menerima opini wajar tanpa pengecualian akan menghindari terjadinya keterlambatan laporan audit (Triyaningtyas dan Sudarno, 2019). Perusahaan akan lebih cepat memberikan informasi tersebut kepada investor dalam penerbitan laporan keuangan. Sebaliknya, jika perusahaan menerima opini selain wajar tanpa pengecualian, auditor akan mencari bukti yang menyebabkan opini selain wajar tanpa pengecualian. Menemukan bukti yang mendukung akan menghabiskan waktu yang banyak sehingga akan memperpanjang keterlambatan laporan audit.

\section{Ukuran Kantor Akuntan Publik dan Keterlambatan Laporan Audit}

Hasil uji hipotesis menunjukkan nilai probabilitas sebesar 0,8048 maka dapat disimpulkan bahwa ukuran kantor akuntan publik tidak berpengaruh terhadap keterlambatan laporan audit. Maka H3 ditolak. Perusahaan yang mengalami keterlambatan laporan audit tidak bergantung pada ukuran kantor akuntan publik, karena kantor akuntan publik yang internasional maupun tidak memiliki sumber daya yang profesional. Berdasarkan hasil uji, dapat disimpulkan KAP internasional dan KAP biasa memiliki kemungkinan mengalami keterlambatan audit. KAP akan berusaha untuk mempertahankan image baik di depan klien sehingga auditor akan berusaha menyelesaikan laporan audit dengan tepat waktu. Image dari KAP sangat penting baik KAP internasional ataupun tidak, karena KAP yang dinilai berkinerja buruk atau lambat, akan kehilangan kesempatan kerja sama jangka panjang dengan klien.

\section{Ukuran Perusahaan dan Keterlambatan Laporan Audit}

Hasil uji hipotesis menunjukkan nilai probabilitas sebesar 0,0003 dan nilai koefisien sebesar 8,361382 maka dapat disimpulkan bahwa ukuran perusahaan berpengaruh signifikan positif terhadap keterlambatan laporan audit. Maka $\mathbf{H 4}$ ditolak. Hasil tersebut menunjukkan bahwa semakin besarnya ukuran suatu perusahaan akan mengalami keterlambatan laporan audit yang lebih tinggi. Perusahaan skala besar memiliki akun yang lebih kompleks dan memiliki kemungkinan menggunakan waktu yang lebih lama untuk 
proses audit. Saldo dan akun yang kompleks akan membuat auditor menggunakan waktu yang lebih lama untuk verifikasi akun dan menggumpulkan bukti-bukti sebagai pendukung transaksi yang telah dilakukan (Mawardi, 2017) dan (Arifuddin et al., 2017).

\section{Leverage dan Keterlambatan Laporan Audit}

Hasil uji hipotesis menunjukkan nilai probabilitas sebesar 0,4814 maka dapat disimpulkan bahwa leverage tidak berpengaruh terhadap keterlambatan laporan audit. Maka $H 5$ ditolak. Perusahaan yang memiliki proporsi hutang yang besar tidak akan mempengaruhi keterlambatan laporan audit. Perusahaan akan berusaha meminimalisir terjadinya keterlambatan laporan audit baik dalam kondisi leverage tinggi ataupun rendah. Auditor akan melaksanakan proses audit dengan menyusun jadwal yang sesuai dengan pengerjaan audit dalam waktu yang tepat Herdjiono dan Sutanti (2018).

\section{Profitabilitas dan Keterlambatan Laporan Audit}

Hasil uji hipotesis menunjukkan nilai probabilitas sebesar 0,0000 dan nilai koefisien sebesar -26,41374 maka dapat disimpulkan bahwa profitabilitas berpengaruh negatif terhadap keterlambatan laporan audit. Maka H6 diterima. Hasil tersebut menunjukkan bahwa perusahaan yang memiliki profitabilitas tinggi akan menghindari keterlambatan laporan audit karena perusahaan ingin membagikan informasi positif ini kepada investor dengan tepat waktu. Jika profitabilitas semakin tinggi, maka dapat meningkatkan kepercayaan publik terhadap perusahaan terkait. Profitabilitas tinggi merupakan good news yang dapat mempengaruhi keputusan investor sehingga perusahaan akan berusaha menerbitkan laporan tahunan dengan tepat waktu (Basuony et al., 2016), (Mazkiyani dan Handoyo, 2017), (Suparsada dan Putri, 2017), (Abdillah et al., 2019).

\section{Konsentrasi Kepemilikan dan Keterlambatan Laporan Audit}

Hasil uji hipotesis menunjukkan nilai probabilitas sebesar 0,7881 maka dapat disimpulkan bahwa konsentrasi kepemilikan tidak berpengaruh terhadap keterlambatan laporan audit. Maka H7 ditolak. Keterlambatan laporan audit suatu perusahaan tidak bergantung pada konsentrasi kepemilikan peruashaan. Karena auditor memiliki kebijakan tersendiri dalam proses audit tanpa dipengaruhi oleh tekanan dari pihak lain. Pemegang saham tersebsar akan berharap laporan audit dan laporan keuangan dapat disajikan dengan tepat waktu, namun keputusan terakhir tetap berada di tangan auditor. Bila auditor menemukan keanehan pada laporan keuangan yang telah disajikan, maka auditor akan menggunakan waktu yang lebih lama untuk proses auditnya (Shin et al.,2016) dan (Abed et al., 2020).

\section{KESIMPULAN}

Berdasarkan hasil penelitian mengenai faktor yang mempengaruhi keterlambatan laporan audit dapat disimpulkan bahwa keterlambatan laporan audit akan dipengaruhi secara signifikan negatif oleh opini audit dan profitabilitas, serta dipengaruhi secara signifikan positif oleh ukuran perusahaan. Sedangkan upaya audit, ukuran kantor akuntan publik, leverage, konsentrasi kepemilikan tidak berpengaruh terhadap keterlambatan laporan audit.

\section{REFERENSI}

Abdillah, M. R., Mardijuwono, A. W., \& Habiburrochman, H. (2019). The Effect of Company Characteristics and Auditor Characteristics to Audit Report Lag. Asian Journal of Accounting Research, 4(1), 129-144. https://doi.org/10.1108/ajar-05-20190042

Abed, S., Bataineh, H., \& Suwaidan, M. (2020). Does Implementing Corporate Governance 
and Ownership Structure Have any Impact on Audit Report Lag and Management Report Lag in Jordan. International Journal of Innovation, Creativity and Change, 13(10), 702-717.

Ahmad, A. C., \& Abidin, S. (2008). Audit Delay of Listed Companies: A Case of Malaysia. International Business Research, 1(4), 32-39. https://doi.org/10.5539/ibr.v1n4p32

Alkhatib, K., \& Marji, Q. (2012). Audit Reports Timeliness: Empirical Evidence from Jordan. Procedia - Social and Behavioral Sciences, 62(1), 1342-1349. https://doi.org/10.1016/j.sbspro.2012.09.229

Arifuddin, Hanafi, K., \& Usman, A. (2017). Company Size, Profitability, and Auditor Opinion Influence to Audit Report Lag on Registered Manufacturing Company in Indonesia Stock Exchange. International Journal of Applied Business and Economic Research, 15(19), 353-367.

Askari, R., \& Moradpour, S. (2016). The Relationship Between Auditor Characteristics and Its Impact on the Audit Report on Companies Listed in the Tehran Stock Exchange. International Journal of Humanities and Cultural Studies, 3(1), 177-190.

Baldacchino, P. J., Grech, L., Farrugia, K., \& Tabone, N. (2017). An Analysis of Audit Report Lags in Maltese Companies. Finance: Current Challenges from Across Europe, 98(1), 161-182. https://doi.org/10.1108/S1569-375920160000098010

Basuony, M. A. K., Mohamed, E. K. A., Hussain, M. M., \& Marie, O. K. (2016). Board Characteristics, Ownership Structure and Audit Report Lag in the Middle East. International Journal of Corporate Governance, 7(2), 180-205. https://doi.org/10.1504/ijcg.2016.078388

Butarbutar, R. S. K., \& Hadiprajitno, P. B. (2017). Analisa Faktor-Faktor yang Berpengaruh Terhadap Audit Report Lag (Studi Empiris pada Perusahaan Manufaktur yang Terdaftar di Bursa Efek Indonesia Tahun 2012-2015 ). Diponegoro Journal Of Accounting, 6(3), 1-12.

Cnbcindonesia.com. 2019. Emiten Kena Sanksi BEI, Bukit Asam Lego Saham Treasuri. Diakses pada 28 September 2021 dari https://www.cnbcindonesia.com.

Diana, P., \& Maggy. (2018). Internal and External Determinants of Audit Delay: Evidence from Indonesian Manufacturing Companies. Accounting and Finance Review, 3(1), 16-25. www.gatrenterprise.com/GATRJournals/index.html

Dura, J. (2017). Pengaruh Profitabilitas, Likuiditas, Solvabilitas, Dan Ukuran Perusahaan Terhadap Audit Report Lag Pada Perusahaan Yang Terdaftar Di Bursa Efek Indonesia. Jurnal Ilmiah Bisnis Dan Ekonomi Asia, 11(1), 64-70. https://doi.org/10.32812/jibeka.v11i1.34

Fiatmoko, A. L., \& Anisykurlillah, I. (2015). Faktor-Faktor yang Berpengaruh Terhadap Audit Delay pada Perusahaan Perbankan. Accounting Analysis Journal, 4(1), 1-10.

Fujianti, L., \& Satria, I. (2020). Firm Size, Profitability, Leverage as Determinants of Audit Report Lag: Evidence From Indonesia. International Journal of Financial Research, 11(2), 61-67. https://doi.org/10.5430/ijfr.v11n2p61

Habib, A. (2014). The New Chinese Accounting Standards and Audit Report Lag. International Journal of Auditing, 1(1), 1-14. https://doi.org/10.1111/ijau.12030

Hassan, Y. M. (2016). Determinants of Audit Report Lag: Evidence from Palestine. Journal of Accounting in Emerging Economies, 6(1), 13-32. https://doi.org/10.1108/jaee-052013-0024

Herdjiono, I., \& Sutanti, N. (2018). Determinants of audit delay: evidence from manufacturing sector of Indonesia. Audit Financiar, 16(3), 373-381. https://doi.org/10.20869/auditf/2018/151/017

Idx.co.id. 2018. Penyampaian Laporan Keuangan Auditan yang Berakhir per 31 Desember 2017. Diakses pada 03 Oktober 2021 dari www.idx.co.id.

Jensen, M. C., \& Meckling, W. H. (1976). Theory of the Firm: Managerial, Behavior, 
Agency Cost and Ownership Structure. Jurnal of Financial Economics, 3(4), 305-360. https://doi.org/10.1177/0018726718812602

Julia. (2020). Effect Financial Ratio, Company Age, Size Public Accountant Firm In Audit Delay. Jurnal Akuntansi, 24(1), 51-66. https://doi.org/10.24912/ja.v24i1.641

Khoufi, N., \& Khoufi, W. (2018). An Empirical Examination of the Determinants of Audit Report Delay in France. Managerial Auditing Journal, 33(8-9), 700-714. https://doi.org/10.1108/MAJ-02-2017-1518

Kompasiana.com. 2021. Prosedur Pengujian Substantif terhadap Siklus Persediaan. Diakses pada 28 September 2021 dari https://www.kompasiana.com.

Kumparan.com. 2020. Pentingnya Pengujian Substantif Terhadap Piutang Usaha. Diakses pada 28 September 2021 dari https://kumparan.com.

Lestari, S. Y., \& Nuryatno, M. (2018). Factors Affecting the Audit Delay and Its Impact on Abnormal Return in Indonesia Stock Exchange. International Journal of Economics and Finance, 10(2), 48-56. https://doi.org/10.5539/ijef.v10n2p48

Liputan6.com. 2017. Belum Sampaikan Laporan Keuangan, BEI Suspensi 17 Saham Emiten. Diakses pada 30 September 2021 dari https://www.liputan6.com.

Liputan6.com. 2021. Daftar 52 Emiten Kena Denda Gara-Gara Belum Sampaikan Laporan Keuangan 2020. Diakses pada 03 Oktober 2021 dari https://www.liputan6.com.

Market.bisnis.com. 2020. 80 Emiten Terlambat Terbitkan Laporan Keuangan 2019. Diakses pada 28 September 2021 dari https://market.bisnis.com.

Mawardi, R. (2017). The Effect of Internal and External Factors to Audit Delay and Timeliness. Jurnal Riset Akuntansi Dan Bisnis Airlangga, 2(1), 165-180. https://doi.org/10.31093/jraba.v2i1.25

Mazkiyani, N., \& Handoyo, S. (2017). Audit Report Lag of Listed Companies in Indonesia Stock Exchange. Jurnal Aplikasi Bisnis, 17(1), 77-95. https://doi.org/10.20885/jabis.vol17.iss1.art5

Ningsih, I. G. A. P. S., \& Widhiyani, N. L. S. (2015). Pengaruh Ukuran Perusahaan, Laba Operasi, Solvabilitas Dan Komite Audit Pada Audit Delay. E-Jurnal Akuntansi Universitas Udayana, 12(3), 481-495.

Oradi, J. (2021). CEO Succession Origin, Audit Report Lag, and Audit Fees: Evidence from Iran. Journal of International Accounting, Auditing and Taxation, 1(1), 1-16. https://doi.org/10.1016/j.intaccaudtax.2021.100414

Putra, V. A., \& Wilopo, R. (2017). The Effect of Company Size, Accounting Firm Size, Solvency, Auditor Switching, and Audit Opinion on Audit Delay. The Indonesian Accounting Review, 7(1), 119-130. https://doi.org/10.14414/tiar.v7i1.956

Rahmawati, S. E., \& Suryono, B. (2015). Pengaruh Faktor Internal Dan Eksternal Perusahaan Terhadap Audit Delay. Jurnal Ilmu Dan Riset Akuntansi, 4(7), 1-17.

Restianti, T., \& Agustina, L. (2018). The Effect of Financial Ratios on Financial Distress Conditions in Sub Industrial Sector Company. Accounting Analysis Journal, 7(1), 2533. https://doi.org/10.15294/aaj.v5i3.18996

Roswyda, M., Salman, P., \& Kamsariaty, K. (2019). Analisis Faktor-Faktor Yang Mempengaruhi Audit Delay Pada Perusahaan Pertambangan Yang Terdaftar Di Bursa Efek Indonesia Periode Tahun 2015-2017. Jurnal Ilmiah Ekonomi Bisnis, 5(1), 319331. https://doi.org/10.35972/jieb.v5i1.251

Saemargani, F. I., \& Mustikawati, I. (2015). Pengaruh Ukuran Perusahaan, Umur Perusahaan, Profitabilitas, Solvabilitas, Ukuran KAP, dan Opini Auditor Terhadap Audit Delay. Jurnal Analisa Akuntansi Dan Perpajakan, 4(2), 1-15. https://doi.org/10.25139/jaap.v2i2.1397

Sari, H. K., \& Priyadi, M. P. (2016). Faktor-Faktor Yang Mempengaruhi Audit Delay Pada Perusahaan Manuaktur Tahun 2010-2014. Jurnal Ilmu Dan Riset Akuntansi, 5(6), 117. 
Sharad, A. (2014). Abnormal Audit Delays, Earnings Quality and Firm Value in the USA. Journal of Financial Reporting and Accounting, 12(1), 21-44.

Shin, I. H., Lee, H. Y., Lee, H. A., \& Son, M. (2016). How Does Human Resource Investment in Internal Control Affect Audit Reporting Lag? Asia-Pacific Journal of Accounting and Economics, 1(1), 1-21. https://doi.org/10.1080/16081625.2015.1135751

Suparsada, N. P. Y. D., \& Putri, I. A. D. (2017). Pengaruh Profitabilitas, Reputasi Auditor, Ukuran Perusahaan, Dan Kepemilikan Institusional Terhadap Audit Delay. E-Jurnal Akuntansi Universitas $\quad$ Udayana, 60-87. https://ojs.unud.ac.id/index.php/Akuntansi/article/view/20800

Suryanto, T. (2016). Audit Delay and Its Implication for Fraudulent Financial Reporting: A Study of Companies Listed in the Indonesian Stock Exchange. European Research Studies Journal, 19(1), 18-31. https://doi.org/10.35808/ersj/503

Triyaningtyas, M., \& Sudarno. (2019). Faktor-Faktor yang Berpengaruh Terhadap Audit Report Lag Laporan Keuangan (Studi Empiris pada Perusahaan Jasa yang Terdaftar Di Bursa Efek Indonesia Tahun 2012-2015). Diponegoro Journal of Accounting, 8(1), 19.

Verawati, N. M. A., \& Wirakusuma, M. G. (2016). Pengaruh Pergantian Auditor, Reputasi Kap, Opini Audit, Dan Komite Audit Dalam Audit Delay. E-Jurnal Akuntansi Universitas Udayana, 17(2), 1083-1111.

Vuko, T., \& Cular, M. (2014). Finding Determinants of Audit Delay by Pooled OLS Regression Analysis. Croatian Operational Research Review, 5(1), 81-91.

Wiryakriyana, A. A. G., \& Widhiyani, N. L. S. (2017). Pengaruh Ukuran Perusahaan, Leverage, Auditor Switching, Dan Sistem Pengendalian Internal Pada Audit Delay. EJurnal Akuntansi, 19(1), 771-798.

Zebriyanti, D. E., \& Subardjo, A. (2016). Faktor-Faktor Yang Berpengaruh Terhadap Audit Delay Pada Perusahaan Perbankan. Accounting Analysis Journal, 5(1), 1-18. https://doi.org/10.15294/aaj.v4i1.7784 